\title{
Short-Term Management of Orthodontic Emergencies at Home in The Time of Covid-19 - A Review
}

ISSN 2637-7780

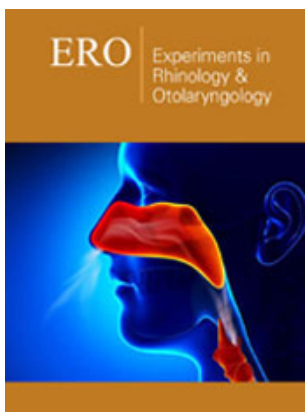

*Corresponding author: Vijay Agarwal, Department of Orthodontics \& Dentofacial Orthopedics, Jaipur Dental College, Jaipur, India

Submission: 覘 September 25, 2020

Published: 眥 October 16, 2020

Volume 3 - Issue 2

How to cite this article: Vijay Agarwal, Ishan Grover, Karamdeep Singh Ahluwalia Lokendra Singh Dagur, Ankur Dhuria. Short-Term Management of Orthodontic Emergencies at Home in The Time of Covid-19 - A Review. Exp Rhinol Otolaryngol 3(2). ERO.000559.2020. DOI: 10.31031/ERO.2020.03.000559

Copyright@Vijay Agarwal, This article is distributed under the terms of the Creative Commons Attribution 4.0 International License, which permits unrestricted use and redistribution provided that the original author and source are credited.

\author{
Vijay Agarwal*, Ishan Grover, Karamdeep Singh Ahluwalia, Lokendra Singh \\ Dagur and Ankur Dhuria
}

Department of Orthodontics \& Dentofacial Orthopedics, Jaipur Dental College, India

\section{Introduction}

The novel Corona virus disease (COVID-19) is an infectious disease caused by a member of the corona virus family (SARS-CoV-2 virus) that probably originated in Wuhan, Hubei, China in December 2019. The disease has spread to almost every country in the world with a sharp increase in the number of cases ever since its origin [1]. The epicentre of the outbreak has been continuously changing and currently the number of cases is showing an exponential growth in India with almost every sector badly affected by the disease [1]. Individuals confirmed with COVID-19 develop symptoms of respiratory tract infection including fever, sneezing, coughing, vomiting, fatigue and severe pneumonia. The disease onset could be mild, moderate, severe or critical. Symptoms among infected individuals may vary from being asymptomatic to Acute Respiratory Distress Syndrome (ARDS), septic shock, multiple organ failures and even death in critical cases [2].

Dental professionals and the patients too can be exposed to this pathogenic microorganism and dental care setups invariably carry the risk of 2019-nCoV infection due to the specificity of its procedures, which involves face-to-face communication with patients, frequent exposure to saliva, and blood, and the handling of sharp instruments. Several studies have reported cross-transmission of COVID-19 among healthcare workers. The disease can transmit from one healthcare worker to another, from healthcare worker to patient, or from patient to patient within the same facility [3]. An orthodontist usually treats several patients in a day who belong to a variable age group. Not just adults but children have also been reported to be asymptomatic carrier of the disease [4,5]. The incubation period of this disease is up to 24 days. The virus is highly contagious during this latency period [6]. This increases the risk of spreading infection within the orthodontic clinic. Furthermore, aerosol generation procedures are confirmed route of infection transmission in dental clinic. The objective of the review is to provide insights on the risks involved, precautions that must be taken in the orthodontic office and management of orthodontic emergencies that the patients can attempt at home. Both the orthodontist as well as the patient has to work together to prevent the cross-contamination of the deadly disease.

\section{Materials and Methodology}

This review includes publications in English and non-English languages that matched the search terms up to August20th, 2020. Studies were retrieved from the following databases: PubMed, MEDLINE, Scopus, CINAHL and Google Scholar. The main author with the help of research assistant conducted the search using the following terms: COVID; COVID-19; 2019nCoV; SARS-CoV-2; Corona; Coronavirus disease; dental; dentist; dentistry; oral; orthodontic; orthodontist; management; infection control; contamination; risks and transmission. Articles that fall within the scope of this review were included and retrieved in full text. References of those articles were screened as well using snowballing technique. Findings of the included studies are discussed below. 


\section{Discussion}

\section{Risk of disease transmission}

Orthodontists, or dentists in general, work in a very close proximity with the patient while performing the treatment procedures. This takes dental healthcare workers at the top of the risk chart of acquiring infectious diseases. The current recommendation by World Health Organization of maintaining a distance of at least 3 feet [7] between individuals is practically not possible in a dental operatory owing to the nature of treatment which makes the orthodontist and the dental assistant highly prone to infection. The incubation period of COVID-19 is as long as 24 days with a tendency of it being contagious throughout this time. This long latency period along with many studies reporting people including children being asymptomatic carriers make it very risky for the orthodontic team [8].

\section{Possible sources of contamination}

Saliva : Saliva is a promising non-invasive specimen for diagnosis, monitoring, and infection control in patients with 2019-nCoV infection with detection of virus in as much as $91.7 \%$ of the COVID positive specimens taken. 9 Since the orthodontist works in close contact with the patient's saliva it is the most common source of contamination.

Aerosol: Using a high-speed airotor handpiece during debonding or ultrasonic scaler during dental cleaning or bracket bonding, produces aerosols, which splatter in the operatory $[9,10]$. This aerosol is very likely to be contaminated with patient's blood, saliva, or high concentrations of infectious microbes like those produced by coughing or sneezing [10]. Moreover, aerosol containing microbes is found to reach as far as 2 meters from the patient's mouth. This means microbes could contaminate surfaces in the entire operatory. The aerosol could contaminate the dental unit waterline, resulting in the spread of infection [11]. Aerosols containing germs of 0.5-
10 microns have the ability to remain airborne for as long as 20 minutes, increasing the risk of being inhaled and posing a potential infectious hazard [12]. This collectively presents an alarming threat with the highly contagious COVID-19.

Orthodontic instruments: Although most of the arch wires are individually packed, there is a huge risk of cross-contamination if some orthodontists re-uses or recycle an improperly sterilized arch wire [13]. In addition, orthodontic brackets, elastomeric chains, photographic retractors, debonding burs, mini screws, orthodontic markers, without proper sterilization and disinfection are a potential hazard. Orthodontic instruments, including band seaters, band removers, pin and ligature cutters, distal end cutters that come in direct contact with patients' saliva and blood are considered dangerous as well [14]. Improper handling and disinfection of such instruments and supplies would compromise infection control measures within the orthodontic practice.

\section{Management of orthodontic emergencies that can be attempted at home}

Following points should be considered while managing orthodontic emergencies from home:

A. Patients should be informed about changes in the orthodontic clinic/office working as per recommendations of the local public health or dental regulatory authority.

B. Patients should be provided with a means of communication (phone number or email) to patients to allow them to contact the orthodontist and even send phone clicked images.

C. Use phone calls or, where possible, video-calling or appropriate tele-dentistry facilities to assist patients in resolving any emergency orthodontic problem that can be managed at home.

D. Patients should also be reminded to always wash their hands prior to and after placing and removing appliances or elastics [14] (Table 1).

Table 1: Advice that can be provided to the patient for short term management of orthodontic emergencies at home.

\begin{tabular}{|c|c|}
\hline Problem & Solution \\
\hline \multirow{2}{*}{$\begin{array}{l}\text { Irritation caused by orthodontic bracket/band or arch wire } \\
\text { on lips/cheek }\end{array}$} & $\begin{array}{l}\text { Application of a small piece of orthodontic relief wax over the bracket or wire that is } \\
\text { causing the irritation. }\end{array}$ \\
\hline & $\begin{array}{c}\text { Topical anaesthetic gels like Orabase (Colgate-Palmolive) or Dologel (Dr. Reddy's } \\
\text { Laboratories Ltd.) } \\
\text { can provide relief from mouth sores. }\end{array}$ \\
\hline \multirow{2}{*}{$\begin{array}{l}\text { Metal ligature which has become loose or is irritating the } \\
\text { mucosa }\end{array}$} & A loose ligature can be removed with the use of a sterile tweezer. \\
\hline & $\begin{array}{l}\text { If pig tail of the ligature is irritating the mucosa, it can be bent with a cotton bud or a } \\
\text { pencil eraser. }\end{array}$ \\
\hline \multirow{3}{*}{ A loose orthodontic bracket or band or molar tube } & $\begin{array}{l}\text { If the bracket has become loose and the patient is unable to visit the orthodontist, the } \\
\text { bracket can be removed } \\
\text { with the help of a sterile tweezer. }\end{array}$ \\
\hline & $\begin{array}{l}\text { If a bracket or tube which is used to anchor the elastics is broken, the use of elastics } \\
\text { should be stopped immediately. }\end{array}$ \\
\hline & $\begin{array}{l}\text { If the last bracket or tube of the arch is losing the bracket or tube can be removed and } \\
\text { the extra wire cut with the help of a nail clipper. The nail cutter should be disinfected } \\
\text { before and after use. }\end{array}$ \\
\hline
\end{tabular}




\begin{tabular}{|c|c|}
\hline \multirow{3}{*}{ Protruding wire at the end of braces } & $\begin{array}{l}\text { A protruding wire is sometimes a result of slipping away of the wire from one side to } \\
\text { the other. } \\
\text { In such a condition a sterile tweezer can be used to pull back the wire }\end{array}$ \\
\hline & Orthodontic relief wax can be used till an appointment is fixed with the orthodontist. \\
\hline & The extra wire can be cut with a sterile nail cutter. \\
\hline \multirow[b]{2}{*}{ Any orthodontic bracket swallowed accidently } & $\begin{array}{l}\text { Orthodontic bracket if swallowed accidently is usually passed though the digestive } \\
\text { tract uneventfully. }\end{array}$ \\
\hline & $\begin{array}{l}\text { Only in cases where after swallowing the patient feels difficulty in breathing or has } \\
\text { sudden coughing, } \\
\text { they are referred to a hospital emergency department. }\end{array}$ \\
\hline \multirow[b]{2}{*}{ Broken bonded retainer } & $\begin{array}{c}\text { If the lingual bonded retainer is completely broken the patient should remove the } \\
\text { entire retainer and start wearing a } \\
\text { removable retainer if provided by the orthodontist }\end{array}$ \\
\hline & $\begin{array}{l}\text { If the retainer is removed from one or two teeth only, the patient should try to bend the } \\
\text { retainer so that } \\
\text { it doesn't hurt or they can attempt to cut the retainer from only these teeth with a } \\
\text { cutter. }\end{array}$ \\
\hline $\begin{array}{l}\text { Severe pain or infection in the gingiva caused by embed- } \\
\text { ding of } \\
\text { part of orthodontic appliance in the gingiva. }\end{array}$ & $\begin{array}{l}\text { An attempt to remove such an appliance especially a piece of wire can be made by } \\
\text { using a sterile } \\
\text { clipper to cut it or a sterile tweezer to pull it out. }\end{array}$ \\
\hline
\end{tabular}

This table is adapted from online resources posted on the website of American Association of Orthodontists, British Orthodontic Society and circulations of the Indian Orthodontic Society. These home remedies can be attempted for short-term management only. However, not all the problems can be solved at home and the patient only in case of serious emergencies should plan an appointment with the orthodontist.

\section{Conclusion}

In this difficult time of COVID 19; the orthodontist, dental office staff and the patient, all should work in synchrony to minimize the risk of transmission of the deadly infection amongst each other. The orthodontist must strictly adhere to the guidelines issued by the concerned authorities and adopt all the necessary preventive measures in the dental office. The patient should also attempt to tackle the emergencies at home after consultation with the orthodontist before planning a visit to the orthodontic office. The orthodontist should also be available through email or over phone/ video call and guide the patient in every possible way. We can conquer this highly contagious virus only by working together and helping each other in emergency situations.

\section{References}

1. https://www.who.int/docs/default-source/coronaviruse/situationreports/20200423-sitrep-94-covid-19.pdf?sfvrsn=b8304bf04 .

2. Peng X, Xu X, Li Y, Cheng L, Zhou X, et al. (2020) Transmission routes of 2019-nCoV and controls in dental practice. Int J Oral Sci 12(9).

3. Rothe C, Schunk M, Sothmann P (2020) Transmission of 2019-nCoV infection from an asymptomatic contact in Germany. N Engl J Med 382: 970-971.
4. Lu X, Zhang L, Du H (2020) SARS-CoV-2 Infection in Children. N Engl J Med 382(17): 1663-1665.

5. Lauer S, Stephen G, Kyra B, Qifang J, Forrest Z, et al. (2020) The Incubation Period of Coronavirus Disease 2019 (COVID-19) from publicly reported confirmed cases: Estimation and application. Annals of Internal Medicine 172(9): 577-582.

6. Arakeri V, Gururaj S, Anand T, Shalini T (2020) Droplet nuclei aerosol and Covid 19 - a risk to healthcare staff. Brit J Oral Max Sur 58(7): 870871.

7. Oliveira G (2020) Refined compartmental models, asymptomatic carriers and COVID-19.

8. To K, Tsang TY, Yip CY, Kwok H, Jacky M (2020) Consistent detection of 2019 novel coronavirus in saliva. Clinical Infectious Diseases 71(15): 841-843.

9. Micik RE, Miller RL, Mazzarella MA, Ryge G (1969) Studies on dental aerobiology. I. Bacterial aerosols generated during dental procedures. J Dent Res 48(1): 49-56.

10. Barnes JB, Harrel SK, Rivera HF (1998) Blood contamination of the aerosols produced by in vivo use of ultrasonic sealers. J Periodontol 69(4): 434-438.

11. Harrel SK, Molinari J (2004) Aerosols and splatter in dentistry: A brief review of the literature and infection control implications. J Am Dent Assoc 135(4): 429-437.

12. Crotty O, Davies E, Jones S (1996) The effects of cross-infection control procedures on the tensile and flextural properties of superelastic nickeltitanium wires. Brit J Orthod 23(1): 37-41.

13. Pernier C, Grosgogeat B, Ponsonnet L, Benay G, Lissac M (2019) Influence of autoclave sterilization on the surface parameters and mechanical properties of six orthodontic wires. Eur J Orthod 27(1): 72-81.

14. Wang Y, Zhou CC, Shu R, Zou J (2020) Oral health management of children during the epidemic period of coronavirus disease 2019 (Chinese). 51(2): 151-154.

For possible submissions Click below: 